\title{
Structure and Mechanical Properties of Ingots and Rolled Sections of Aluminum Alloy Based on the Al-Mg-Mn System
}

\author{
B. V. Ovsyannikov ${ }^{a}$, P. L. Reznik ${ }^{b}$, V. M. Zamyatin ${ }^{b}$, and N. M. Doroshenko ${ }^{a}$ \\ ${ }^{a}$ Kamensk-Uralsk Metallurgical Plant, Kamensk-Uralsk, Russia \\ ${ }^{b}$ Ural Federal University, Yekaterinburg, Russia \\ Received February 21, 2012
}

\begin{abstract}
Commercial ingots and hot-pressed rolled sections of $\mathrm{Al}-\mathrm{Mg}-\mathrm{Mn}$ alloy doped with zinc, scandium, zirconium, chromium, and vanadium have been studied using optical microscopy, thermal analysis, electron microscopy, and electron-probe microanalysis. The compositions of the phase constituents and aluminum matrix of the alloy are determined. The sensitivity of the alloy to the formation of complex intermetallic compounds during solidification is revealed. The mechanical properties of ingots and rolled sections are determined.
\end{abstract}

DOI: $10.1134 / \mathrm{S} 0036029513010102$

\section{INTRODUCTION}

Non-heat-treatable $\mathrm{Al}-\mathrm{Mg}-\mathrm{Mn}$ alloys are widely applied as structural materials for modern engineering $[1,2]$. One of the promising wrought aluminum alloys is $\mathrm{Al}-\mathrm{Mg}-\mathrm{Mn}$ alloy 1580 developed at the KamenskUralsk Metallurgical Plant [3]. This alloy is doped with several transition metals in order to use it for the production of hot-pressed rolled sections with a high (up to $320 \mathrm{MPa}$ ) yield strength.

The purpose of this work is to study the structure and properties of the grade 1580 alloy ingots and rolled sections.

\section{EXPERIMENTAL}

The grade 1580 alloy was produced in a gas furnace using two heats. The chemical composition of the metal of both heats (Table 1) was determined by atomic emission spectroscopy using a Spectrolab spectrometer.

Ingots $270 \mathrm{~mm}$ in diameter were produced by semicontinuous casting with homogenizing annealing at $360-380^{\circ} \mathrm{C}$ for $8 \mathrm{~h}$. Transverse templates from the top of the cast were sampled in order to analyze the structure and properties of the ingots. After removal of a 5-mm-thick surface layer by grinding, the ingots were cut into pieces $850 \mathrm{~mm}$ in length, which were used for preparing rolled sections with a cross section of $50 \times$ $100 \mathrm{~mm}$. The samples for studying the structure and properties were taken from the exit (E) and pullingdown $(\mathrm{P})$ ends of hot-pressed rolled sections.

The phase transformation temperatures of the grade 1580 alloy were determined by thermal analysis with subsequent numerical differentiation with respect to the heating curve time [4]. To reveal the macrostructure of the ingots and rolled sections, we used an aqueous solution of $\mathrm{NaOH}(10-15 \%)$. The grain structure of anodized polished sections was studied using polarized light on an OLYMPUS GX-71 optical microscope. The microstructure and composition of phase constituents were analyzed with a JSM 5900LV scanning electron microscope equipped with a microanalyzer. The mechanical properties of the ingots and hot-pressed rolled sections were tested by conventional methods.

\section{RESULTS AND DISCUSSION}

Cold shuts with a depth of $2-3 \mathrm{~mm}$ and a period of 20-25 $\mathrm{mm}$ along an ingot are visible on the surface of the as-cast ingots ( $270 \mathrm{~mm}$ in diameter). The structure

Table 1. Chemical composition of grade 1580 alloy*

\begin{tabular}{c|c|c|c|c|c|c|c|c|c|c|c}
\hline \multirow{2}{*}{ Heat } & \multicolumn{10}{c}{ Element content, wt \% } \\
\cline { 2 - 12 } & $\mathrm{Mg}$ & $\mathrm{Mn}$ & $\mathrm{Zn}$ & $\mathrm{Sc}$ & $\mathrm{Zr}$ & $\mathrm{Cr}$ & $\mathrm{V}$ & $\mathrm{Cu}$ & $\mathrm{Fe}$ & $\mathrm{Si}$ & $\mathrm{Be}$ \\
\hline 1 & 6.3 & 1.0 & 0.8 & 0.25 & 0.09 & 0.12 & 0.014 & 0.18 & 0.07 & 0.07 & 0.0006 \\
2 & 6.3 & 1.1 & 0.5 & 0.23 & 0.10 & 0.11 & 0.015 & 0.10 & 0.06 & 0.06 & 0.0004 \\
\hline
\end{tabular}

* Aluminum for balance. The hydrogen content in the alloy is $0.46 \mathrm{~cm}^{3} / 100 \mathrm{~g}$. 


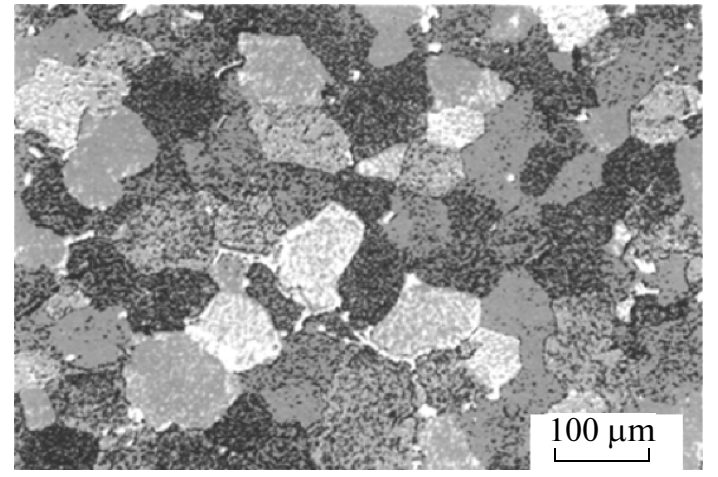

Fig. 1. Structure of an ingot $270 \mathrm{~mm}$ in diameter made of the grade 1580 alloy.

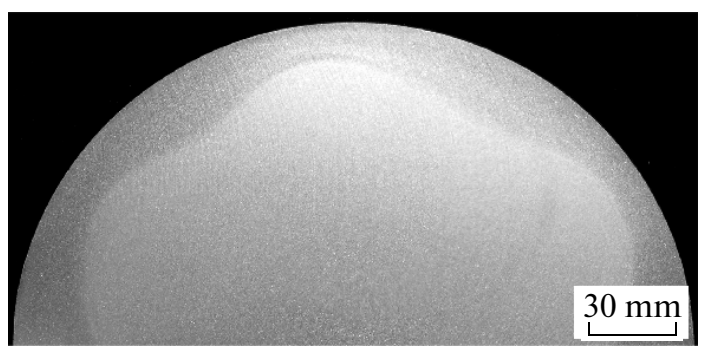

Fig. 2. Cross-section macrostructure of a grade 1580 alloy ingot $270 \mathrm{~mm}$ in diameter.

of the ingots is homogeneous, fine-grained, and close to a polyhedral pattern (Fig. 1).

The average grain size increases linearly from 30 to $40 \mu \mathrm{m}$ from the surface region of an ingot to the central part. In the cross section of the ingot, a heterogeneity of macrostructure is revealed in the form of a bright region (Fig. 2). An analysis of the distribution of alloying and impurity elements over the cross section of the ingot showed that $1.3 \% \mathrm{Mn}$ and $6.2 \% \mathrm{Mg}$ are contained in the bright region and $1.0 \% \mathrm{Mn}$ and $6.5 \%$ $\mathrm{Mg}$ are present in the peripheral dark region. Therefore, the central region contains a higher amount of manganese and a lower amount of magnesium in comparison with the peripheral region. The distribution of the other elements over the ingot cross section is uniform.

Separate coarse particles and clusters of intermetallic compounds $\mathrm{Al}_{6}(\mathrm{Mn}, \mathrm{Cr}, \mathrm{Ti}, \mathrm{V})$ and $\mathrm{Al}_{6}(\mathrm{Mn}, \mathrm{Fe}, \mathrm{Cr})$ of a variable chemical composition are observed in the microstructure of the ingots (Fig. 3, Table 2; points 1, $1 a, 1 b)$. The particle sizes of these intermetallic compounds are from $35 \times 42$ to $90 \times 230 \mu \mathrm{m}$, and some clusters contain up to 16 intermetallic particles. In addition, the microstructure also contains fine spherical particles (Fig. 3, Table 2; points 3,3a), which consist of intermetallic compound $\mathrm{Al}_{5}(\mathrm{Sc}, \mathrm{Zr}, \mathrm{Ti})$. These particles exist in the form of clusters along grain boundaries and on the surface of intermetallic compounds $\mathrm{Al}_{6}(\mathrm{Mn}, \mathrm{Cr}, \mathrm{Ti}, \mathrm{V})$ and $\mathrm{Al}_{6}(\mathrm{Mn}, \mathrm{Fe}, \mathrm{Cr})$.

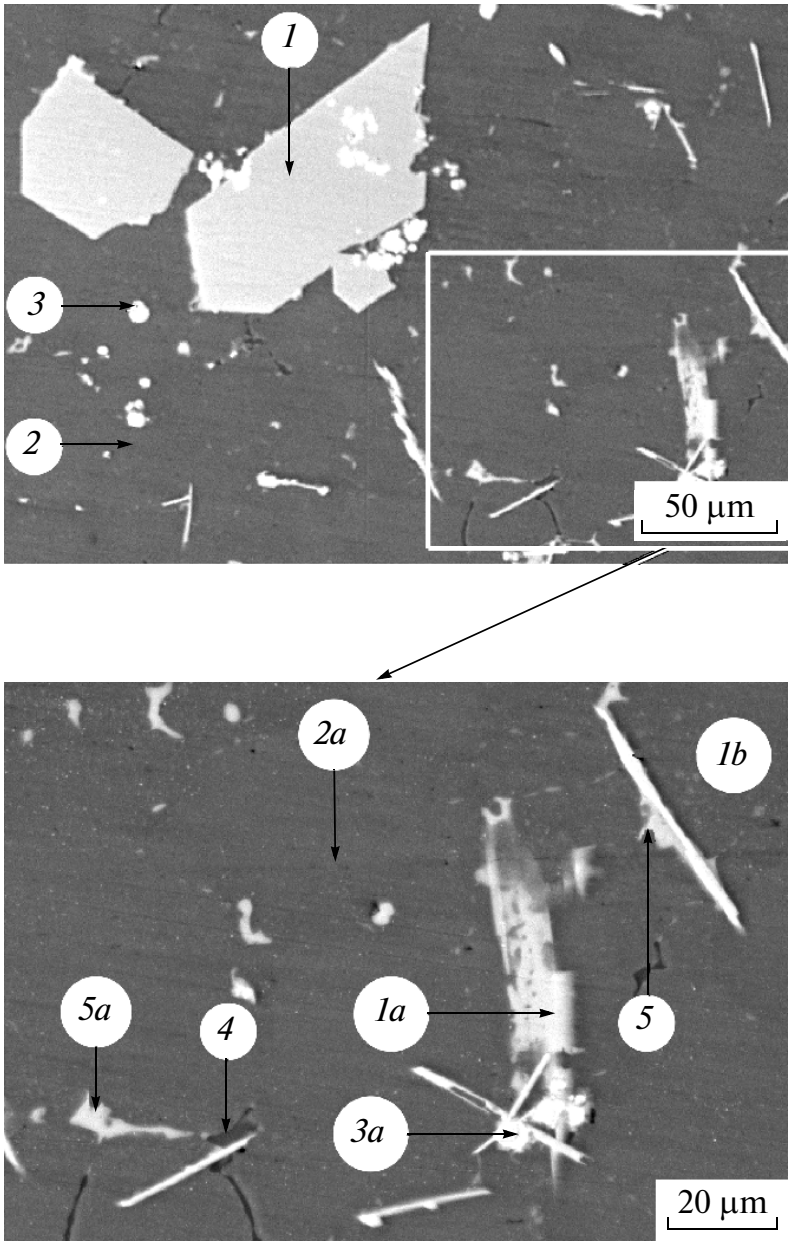

Fig. 3. Micrograph of part of the polished section from the central layers of a grade 1580 alloy ingot $270 \mathrm{~mm}$ in diameter taken with backscattered electrons: EPMA points are given in Table 2.

Several regions of the polished section contain a complex eutectic (Fig. 3, Table 2, points 5, 5a) in the form of layers along grain boundaries. However, the volume fraction of the eutectic layers is insignificant.

$\alpha_{\mathrm{Al}}$ solid solution grains contain $6.12-6.26 \% \mathrm{Mg}$, $0.61-0.81 \% \mathrm{Mn}, 0.08-0.13 \% \mathrm{Cr}, 0.19-0.22 \% \mathrm{Sc}$, $0.16-0.19 \% \mathrm{Cu}, 0.09 \% \mathrm{Zr}$, and $0.04-0.05 \% \mathrm{Fe}$.

To determine the phase transformation temperatures, we used thermal analysis of the grade 1580 alloy in a heating mode. The obtained thermogram (Fig. 4) shows that the melting temperature range of the nonequilibrium eutectic (nonequilibrium solidus) is 466$477^{\circ} \mathrm{C}$, the equilibrium solidus temperature is $536^{\circ} \mathrm{C}$, and the liquidus temperature is $621^{\circ} \mathrm{C}$.

To find the temperature range of the maximum plasticity of the grade 1580 alloy ingots, we determined the temperature dependence of the mechanical properties of samples (Fig. 5). The samples were cut in a radial direction. The data obtained evidence that relative elongation $\delta$ and relative reduction of area $\psi$ of 


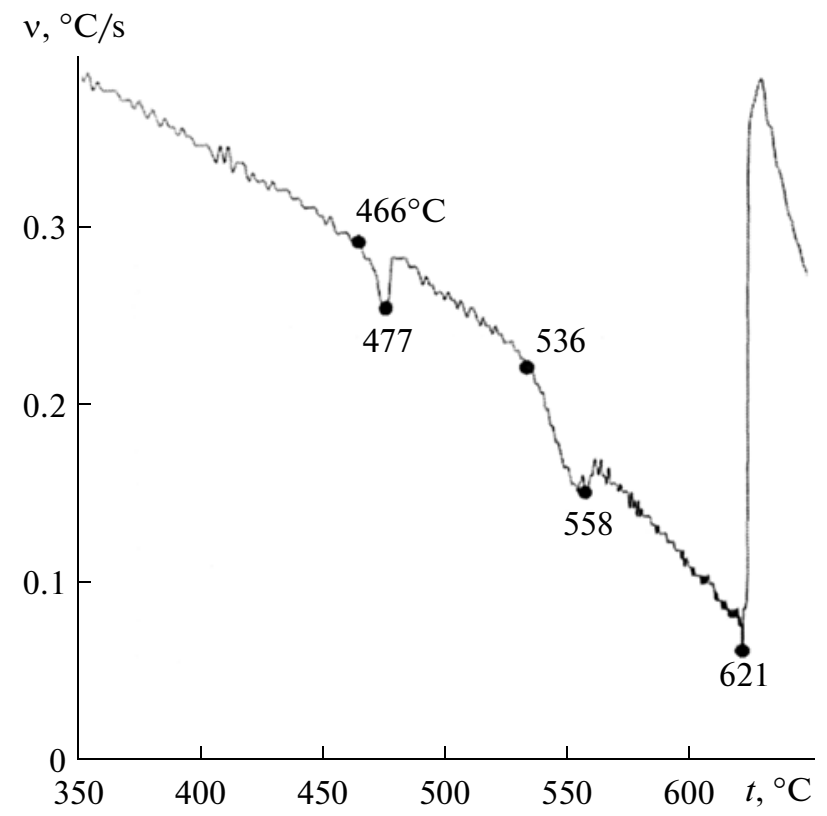

Fig. 4. Heating thermogram of a sample cut from a homogenized grade 1580 alloy ingot $270 \mathrm{~mm}$ in diameter.

the samples are maximal at $430^{\circ} \mathrm{C}$. At this temperature, the alloy is characterized by a yield strength $\sigma_{0.2}=38-39 \mathrm{MPa}$ and ultimate tensile strength $\sigma_{\mathrm{u}}=$ 43-44 MPa.

Taking into consideration that the plastic properties $(\delta, \psi)$ of the ingots in the temperature range are maximal, this temperature range was chosen as the upper temperature range for hot pressing of rolled sections. In addition to hot pressing in this temperature range, the rolled sections were also pressed at lower temperatures (Table 3).

The macrostructure of all pressed sections is characterized by heterogeneity, which consists in the fact (a)
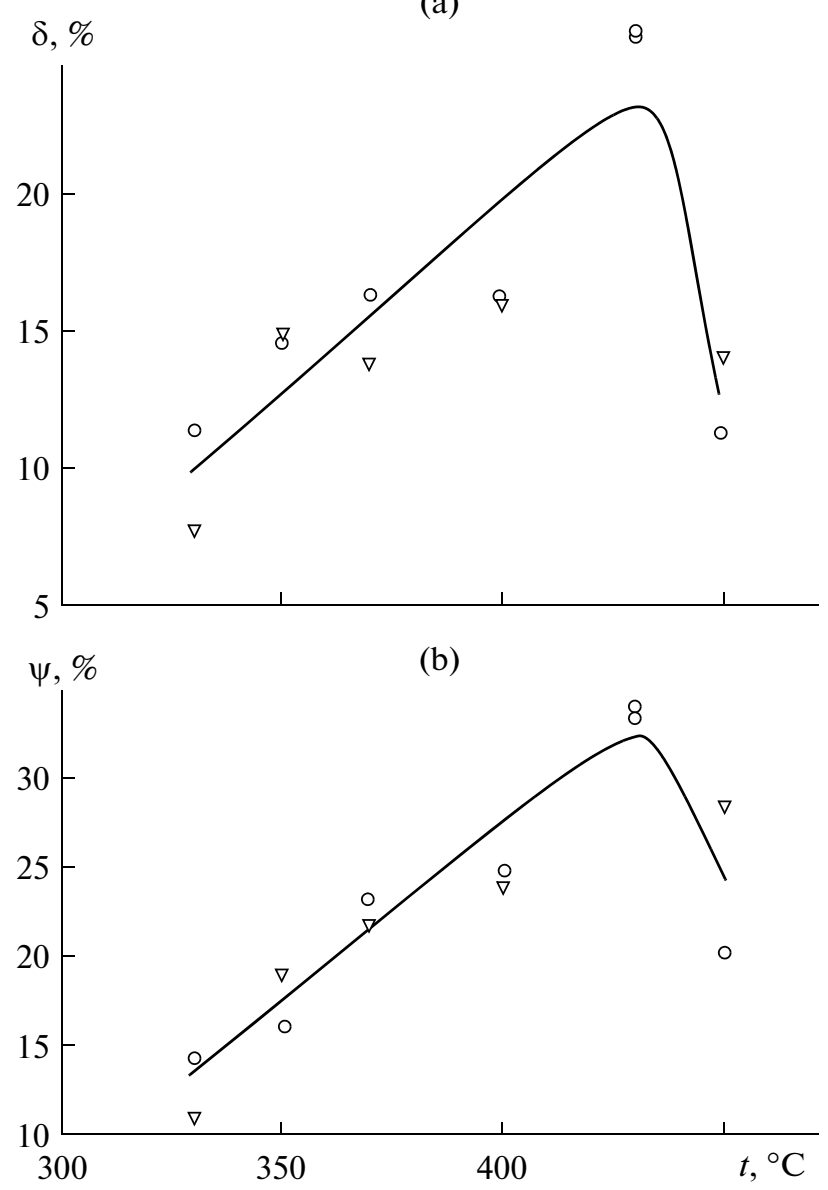

Fig. 5. Temperature dependences of (a) relative elongation $\delta$ and (b) relative reduction of area $\psi$ (b) of a grade 1580 alloy ingot $270 \mathrm{~mm}$ in diameter: $(O)$ heat 1 and $(\nabla)$ heat 2 .

that their central part is bright as compared to the periphery. This peculiarity of the macrostructure of the rolled sections is inherited from the ingot.

Table 2. EPMA results for the composition of the phase constituents of grade 1580 alloy ingots

\begin{tabular}{|c|c|c|c|c|c|c|c|c|c|c|c|c|}
\hline \multirow{2}{*}{$\begin{array}{l}\text { Point } \\
\text { (see } \\
\text { Fig. 3) }\end{array}$} & \multicolumn{11}{|c|}{ Element content, wt \% } & \multirow{2}{*}{ Compound } \\
\hline & $\mathrm{A} 1$ & $\mathrm{Mn}$ & $\mathrm{Cr}$ & $\mathrm{Mg}$ & $\mathrm{Fe}$ & $\mathrm{Ti}$ & $\mathrm{Sc}$ & $\mathrm{Cu}$ & $\mathrm{Zr}$ & $\mathrm{Si}$ & $\mathrm{V}$ & \\
\hline 1 & 72.98 & 17.72 & 6.60 & - & 0.56 & 0.72 & - & - & - & - & 0.37 & $\mathrm{Al}_{6}(\mathrm{Mn}, \mathrm{Cr}, \mathrm{Ti}, \mathrm{V})$ \\
\hline $1 a$ & 67.32 & 18.76 & 2.03 & - & 4.92 & - & - & - & - & - & - & $\mathrm{Al}_{6}(\mathrm{Mn}, \mathrm{Fe}, \mathrm{Cr})$ \\
\hline $1 b$ & 65.79 & 17.31 & 1.54 & - & 5.41 & - & - & - & - & - & - & $\mathrm{Al}_{6}(\mathrm{Mn}, \mathrm{Fe}, \mathrm{Cr})$ \\
\hline 2 & 91.62 & 0.81 & 0.08 & 6.12 & 0.04 & - & 0.22 & 0.16 & 0.09 & - & - & $\alpha_{\mathrm{Al}}$-solid solution \\
\hline $2 a$ & 91.68 & 0.61 & 0.13 & 6.26 & 0.05 & - & 0.19 & 0.19 & 0.09 & - & - & $"$ \\
\hline 3 & 58.15 & - & - & - & - & 1.83 & 16.37 & - & 21.51 & - & - & $\mathrm{Al}_{5}(\mathrm{Sc}, \mathrm{Zr}, \mathrm{Ti})$ \\
\hline $3 a$ & 59.36 & - & - & - & - & 1.46 & 19.43 & - & 18.06 & - & - & $\mathrm{Al}_{5}(\mathrm{Sc}, \mathrm{Zr}, \mathrm{Ti})$ \\
\hline 4 & 25.64 & - & - & 43.69 & - & - & - & - & - & 27.83 & - & $\mathrm{Mg}_{2} \mathrm{Si}$ \\
\hline 5 & 49.06 & - & - & 26.43 & - & - & - & 10.71 & & $13.12 \mathrm{Zn}$ & & $\begin{array}{l}\text { Eutectic of com- } \\
\text { plex composition }\end{array}$ \\
\hline $5 a$ & 49.24 & - & - & 26.52 & - & - & - & 11.16 & & $12.67 \mathrm{Zn}$ & & The same \\
\hline
\end{tabular}


Table 3. Mechanical properties of $50 \times 100 \mathrm{~mm}$ rolled sections of the grade 1580 alloy as a function of pressing temperature $t_{\mathrm{pr}}$

\begin{tabular}{|c|c|c|c|c|c|}
\hline \multirow{3}{*}{$t_{\mathrm{pr}},{ }^{\circ} \mathrm{C}$} & \multirow{3}{*}{ Rolled section } & \multirow{3}{*}{ Sample* } & \multicolumn{3}{|c|}{ Mechanical property } \\
\hline & & & $\sigma_{\mathrm{u}}$ & $\sigma_{0.2}$ & \multirow{2}{*}{$\delta, \%$} \\
\hline & & & \multicolumn{2}{|c|}{ MPa } & \\
\hline $300-350$ & 1 & $\begin{array}{l}1 \mathrm{E} \\
1 \mathrm{P}\end{array}$ & $\begin{array}{l}433 \\
435\end{array}$ & $\begin{array}{l}282 \\
296\end{array}$ & $\begin{array}{l}15.0 \\
15.0\end{array}$ \\
\hline \multirow[t]{2}{*}{$350-400$} & 2 & $\begin{array}{l}2 \mathrm{E} \\
2 \mathrm{P}\end{array}$ & $\begin{array}{l}445 \\
452\end{array}$ & $\begin{array}{l}304 \\
307\end{array}$ & $\begin{array}{l}15.5 \\
14.0\end{array}$ \\
\hline & 3 & $\begin{array}{l}3 E \\
3 P\end{array}$ & $\begin{array}{l}426 \\
439\end{array}$ & $\begin{array}{l}280 \\
290\end{array}$ & $\begin{array}{l}16.0 \\
14.5\end{array}$ \\
\hline \multirow[t]{2}{*}{$400-450$} & 4 & $\begin{array}{l}4 \mathrm{E} \\
4 \mathrm{P}\end{array}$ & $\begin{array}{l}436 \\
444\end{array}$ & $\begin{array}{l}288 \\
307\end{array}$ & $\begin{array}{l}13.5 \\
14.5\end{array}$ \\
\hline & 5 & $\begin{array}{l}5 \mathrm{E} \\
5 \mathrm{P}\end{array}$ & $\begin{array}{l}439 \\
434\end{array}$ & $\begin{array}{l}304 \\
288\end{array}$ & $\begin{array}{l}12.5 \\
15.0\end{array}$ \\
\hline
\end{tabular}

Note: The container temperature is $400-420^{\circ} \mathrm{C}$, and the pressing rate is $0.4 \mathrm{~m} / \mathrm{min}$.

* E is the exit end of rolled section, and $\mathrm{P}$ is the pulling-down end of the rolled section.

The microstructure of hot-pressed $50 \times 100 \mathrm{~mm}$ rolled sections contains fragmented intermetallic compounds located as lines along the pressing direction (Fig. 6). Electron-probe microanalysis (EPMA) of these coarse particles showed that they consist of the $\mathrm{Al}_{6}(\mathrm{Mn}, \mathrm{Cr}, \mathrm{Ti}, \mathrm{V})$ and $\mathrm{Al}_{6}(\mathrm{Mn}, \mathrm{Fe}, \mathrm{Cr})$ intermetallic compounds, which are identical to those in the ingots. In addition, the microstructure of the samples contains lines of fine particles of intermetallic compound $\mathrm{Al}_{5}(\mathrm{Sc}, \mathrm{Zr}, \mathrm{Ti})$.

The results of testing the mechanical properties of the exit and pulling-down ends of the rolled sections at room temperature are summarized in Table 3. An analysis of the tabulated data shows that the level of mechanical properties of the alloy 1580 rolled section is actually independent of the temperature of their

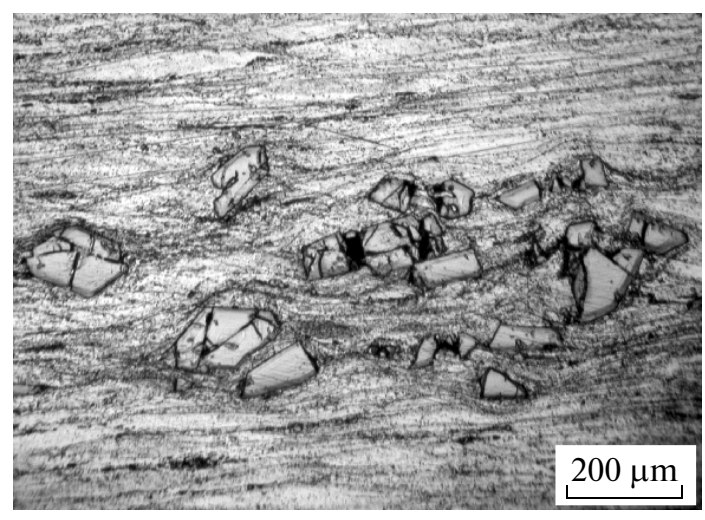

Fig. 6. Microstructure of hot-pressed $50 \times 100-\mathrm{mm}$ rolled sections in the longitudinal direction. pressing, all other things being equal. However, commercial tests revealed that cracks formed in the corner zones during hot pressing of the rolled sections in the temperature range $350-400^{\circ} \mathrm{C}$ because of the insufficient technological plasticity of the alloy. Cracks formed most frequently in pressing of the rolled sections in the temperature range $300-350^{\circ} \mathrm{C}$.

Therefore, the plastic properties of the ingots in the temperature range of their pressing and the mechanical properties of the rolled sections can be improved by means of preventing the formation or a significant reduction of the volume fraction of intermetallic compounds $\mathrm{Al}_{6}(\mathrm{Mn}, \mathrm{Cr}, \mathrm{Ti}, \mathrm{V}), \quad \mathrm{Al}_{6}(\mathrm{Mn}, \mathrm{Fe}, \mathrm{Cr}), \quad$ and $\mathrm{Al}_{5}(\mathrm{Sc}, \mathrm{Zr}, \mathrm{Ti})$ in their structure. This can be achieved by correcting the chemical composition of the alloy in the content of transition metals and by increasing the cooling rate of an ingot in the temperature range of alloy solidification.

\section{CONCLUSIONS}

(1) Homogenized ingots of the grade 1580 alloy $270 \mathrm{~mm}$ in diameter have a fine-grained macrostructure. The central zone of the ingots contains macroheterogeneity, which is caused by a high manganese concentration and a low magnesium content in comparison with the peripheral zone. It was found that the microstructure of the ingots contains coarse particles of intermetallic compounds $\mathrm{Al}_{6}(\mathrm{Mn}, \mathrm{Cr}, \mathrm{Ti}, \mathrm{V})$ and $\mathrm{Al}_{6}(\mathrm{Mn}, \mathrm{Fe}, \mathrm{Cr})$ and fine globular particles of compound $\mathrm{Al}_{5}(\mathrm{Sc}, \mathrm{Zr}, \mathrm{Ti})$. The plasticity properties of the ingots at testing temperatures of $400-430^{\circ} \mathrm{C}$ are insufficient for hot pressing of rolled sections without cracking in them. 
(2) The macrostructure of hot-pressed rolled sections is characterized by the macroheterogeneity inherited from the ingots. The microstructure of the rolled sections contains fragments of intermetallic compounds, which formed during pressing. They are located in the form of lines oriented along the pressing direction. As a consequence, the yield strengths of the rolled sections are below the expected level.

\section{REFERENCES}

1. I. N. Fridlyander, Aluminum wrought engineering alloys (Metallurgiya, Moscow, 1979).
2. Aluminum: Properties and physical metallurgy, Ed. by J. E. Hatch (American Society for Metals, Metals Park, Ohio, 1984).

3. B. V. Ovsyannikov, V. V. Zakharov, Yu. A. Filatov, and V. M. Chertovikov, "Aluminum-based alloy," RF Patent 2387725, Byull. Izobret., No. 12 (2010).

4. V. L. Smirnov, V. M. Zamyatin, B. V. Ovsyannikov, and V. S. Mushnikov, "Thermal analysis of melting and solidifying of aluminum alloys," Tsvetn. Metal., No. 2, 80-82 (2009).

Translated by I. Moshkin 